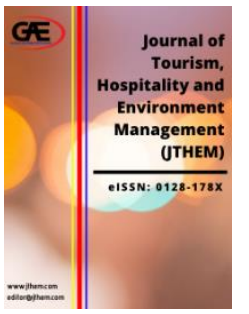

\author{
JOURNAL OF TOURISM, \\ HOSPITALITY AND \\ ENVIRONMENT MANAGEMENT \\ (JTHEM) \\ www.jthem.com
}

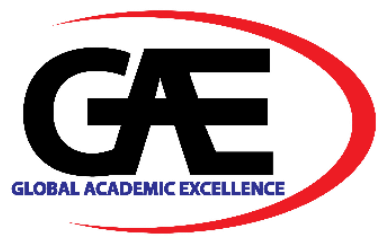

\title{
AN EFFECTIVENESS OF STRATEGIC LAND DEVELOPMENT ON SEWERAGE PLANNING AND LAND SERVICES IN INDAH WATER KONSORTIUM SDN BHD
}

\author{
Muhamad Zuraini Idris ${ }^{1 *}$, Robiah Suratman ${ }^{2}$, Salfarina Samsudin ${ }^{3}$
}

1 Department of Real Estate, Faculty of Built Environment and Survey, Universiti Teknologi Malaysia, Johor Bahru, Malaysia

Email: zuraini4879@gmail.com

2 Department of Real Estate, Faculty of Built Environment and Survey, Universiti Teknologi Malaysia, Johor Bahru, Malaysia

Email: robiah@utm.my

3 Department of Real Estate, Faculty of Built Environment and Survey, Universiti Teknologi Malaysia, Johor Bahru, Malaysia

Email: salfarina.utm@gmail.com

* Corresponding Author

\section{Article Info:}

\section{Article history:}

Received date: 01.10 .2021

Revised date: 01.11.2021

Accepted date: 15.11.2021

Published date: 01.12.2021

\section{To cite this document:}

Idris, M. Z., Suratman, R., \& Samsudin, S. (2021). An Effectiveness Of Strategic Land Development On Sewerage Planning And Land Services In Indah Water Konsortium Sdn Bhd. Journal of Tourism Hospitality and Environment Management, 6 (26), 121-129.

DOI: $10.35631 /$ JTHEM.626010.

This work is licensed under CC BY 4.0

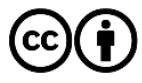

\begin{abstract}
:
The higher demanding factor for residential and commercial units has seen an increasing number of STP maintained by IWK every year. This increasing number of STP has forced IWK to incur increased operating and maintenance costs. With a limited number of employees and a large catchment area, it has raised several issues and problems such as the issue of encroachment into the STP land. To overcome the issues and problems, strategic land development is needed where it is also a method in achieving sustainable development. This study used a qualitative method by analyzing the current work procedures or guidelines and government documents used by IWK such as the Federal Constitution of Malaysia, National Land Code, and Malaysian Sewerage Industry Guidelines. The findings of the study found that the function of IWK in sewerage land management for public STP and the former STP site is quite limited. Thus, a new procedure or guidelines need to be developed to improve these weaknesses. Based on the land issues faced by IWK, it shows that the strategic land development will be able to help IWK in the planning stages in the future effectively. While sustainable development can be achieved by IWK using a combination between the new land management model and GIS application. This new land management model needs to be combined and should include all the existing procedures or guidelines and be controlled by one unit only. GIS as the most powerful tool today seen can help IWK to manage all the matter related sewerage lands, such as finding the decommissioned STP site, selecting the new location for
\end{abstract}




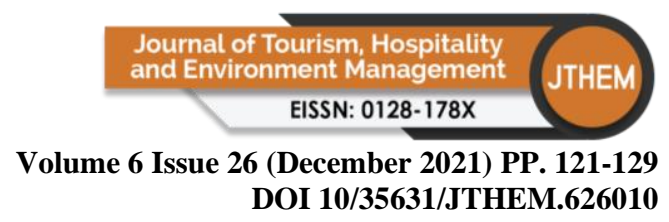

the Regional STP project, and selection of the new alignment for a property connection project. Indirectly, it can help IWK to reduce the cost of operation and maintenance, sewerage land issues, environmental issues, and others.

Keywords:

Strategic Land Development, Geographical Information System, Public Sewerage Site, Sewerage Land Management

\section{Introduction}

The rapid development process today had seen the demanding units for residential and commercial was increased in this country. This has led to an increasing number of the sewerage treatment plant (STP) nationwide maintained by the Indah Water Konsortium Sdn Bhd (IWK). As of February 2021, the total number of STP maintained by IWK is 11,839 in Peninsular Malaysia involving 102 local authorities (LA). This increasing number of STP every year had given an impact on IWK's financial status as well as the impact on the environment. Based on the Planning Guidelines for Housing Scheme issued by the Federal Department of Town Planning and Country Planning (Plan Malaysia) on $18^{\text {th }}$ September 2014 , it requires that every housing scheme that has exceeded 30 units, the developer need to provide the STP. This requirement is stated in the guideline under item 7.11, which is the provision of infrastructure facilities and utilities.

Thus, the existence of the new development areas has increased the number of the STP every year. At the same time, IWK as the national sewerage company need to spend an extra cost to do the operation and maintenance works (Kumpulan Media, Karangkraf, 2018). With the lower tariff has been charged to their customers, it saw IWK constantly losing their profit since established in year 1994 (Berita Harian, 2012). In order to reduce the increasing number of the new STP every year, the Regional Planning Unit (RPU) has taken an initiative in giving an advice to the developer in connecting the Population Equivalent (PE) of their development to the existing STP maintained by the IWK. This initiative seen can help the IWK to reduce their operation and maintenance cost. Another initiative taken by IWK to reduce the increasing of operating costs is using closing the small and uneconomical STPs such as through the rationalization program, properties connection project and cost optimization. The result of this initiative has created a lot of former STP sites that are not used properly where it has a great potential to be redeveloped. Besides that, it also can give a negative impact on the environment and to the local community. The former STP sites will cause an odor pollution as well as noise pollution if not maintained properly. If this issue is not well managed, it can arise the problems in the surrounding communities such as give a negative impact on psychology, physiology and human health (Mohd Rozaimi Ariffin, Zaini Sakawi \& Lukman Ismail, 2013).

Based on these problems, a strategic land development plan seen is needed. Jan Nederveen (2001), states that the development is an economic growth, development of science and technology where it is begins with infrastructure works such as a road, highway and others. In another words, the advancement of science and technology will influence the pattern of the development. High advances in science and technology will build complex and practical developments for the use of an increasingly developed and competitive society. While the land redevelopment is to carried out the purpose of strengthening economic activities in the 


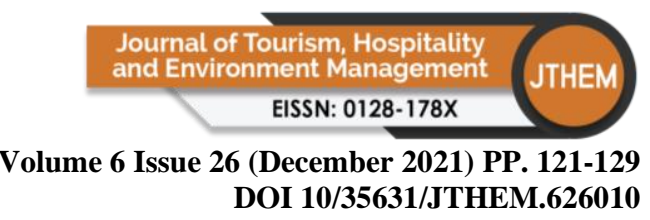

city center as well as being able to improve the physical condition of the city (Bunnell et.al, 2002).

Today, the application of Geographic Information System (GIS) is seen very suitable to be used in the strategic land development planning process. This is because GIS application is a most powerful tools today that can be used in the decision making process especially related to a spatial problems (Ruslan and Noresah, 2004). Through the ability of GIS application, it is able to process, manage, analyze and present geospatial data easily and comprehensively (Fotheringham and Wilson, 2008). In addition, the data and an information from various sources can be integrated to assist the user in decision making process purposes (Masser, 2001). This will make the GIS application an important tools in processing and analyzing the data from the real world to the virtual world (Silvera et.al, 1996).

The main objective of this study is to analyze and review the existing procedures and guidelines used by IWK in the process of handing over sewerage site and looking for the current land management of STP as a basis for the formation of a more efficient land model. Therefore, it can be concluded that the strategic land development must be include the main factors such as a long term planning and an impact on the environment in order to achieve the objective of sustainable development.

\section{Literature Review}

The literature review is a combination of information obtained from secondary sources such as a newspaper, magazines, journals, books, theses, papers, documents and others. The purpose of a literature review is to gain an understanding of the existing research and debates relevant to a particular topic or area of study, and to present that knowledge in the form of a written report. Doing a literature review will help a researcher to develop a theoretical analysis, to build the design of the study to be done, to design the method of data collection and to find the way of the data to be analysed. In conducting this study, the researcher has learned, studied and analysed the existing procedures and guidelines used by IWK in the process of handing over the land owned by the developer to the IWK for sewerage site's purpose. The researcher also looking for the current land management of the sewerage site until it is handed back to the Sewerage Service Department (JPP) when it is no longer used. This existing procedures and guidelines is used by the State Certifying Agency Unit (CA), Regional Land Unit (RLU), Operation Unit (UO) and RPU. In addition, the researcher also has analysed a several government documents used in the process of handover and land management of sewerage sites such as the Federal Constitution (FC), National Land Code 1965 (NLC) and Malaysian Sewerage Industry Guidelines $3^{\text {rd }}$ Edition, Volume 4 (MSIG) where is interrelated with each other. The result of the analysis of the procedures, guidelines and government documents used by IWK is as follows.

\section{An Existing of IWK Procedures and Guidelines}

Currently, there has a several procedures and guidelines used by IWK related to the process of handing over and land management of the sewerage sites. It is beginning from handing over process of land owned by the developer to IWK to be gazetted as a "public sewerage site' until this land was handed back to the JPP when it is no longer used. The process of handing over of land owned by the developer to IWK was started by the CA. After the IWK has agreed to take over the STP, the developer at the same time is required to hand over the land belong to them to IWK before it will gazetted as a 'public sewerage site'. According to 


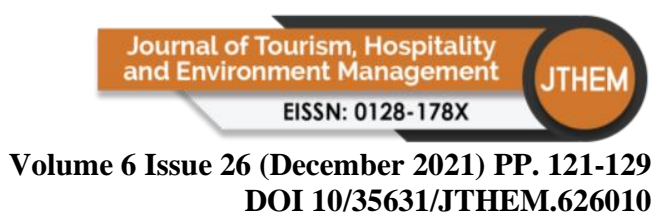

the existing procedures, $\mathrm{CA}$ will prepare and compile all the documentation and forms related to NLC such as Form 12A, Form 12B, Form 12C and Form 14A before forwarded it to RLU for their next further action. Then the RLU will check all the documentation received by $\mathrm{CA}$ in order to ensure it is completed before verifying the STP site on the ground.

Currently, there has a three procedures used by RLU, it is land verification, land reservation and land acquisition. The purpose of land verification is to ensure that the land verification, such as land status, area, ownership of sewerage sites is identified and a land plan and photograph are produced. Land reservation objective is to ensure all land for sewerage works is approved and gazetted to the Federal Lands Commissioner (FLC) while the purpose of land acquisition is to ensure that the proposed site for sewerage project is acquired according to the provisions of the Land Acquisition Act 1960 (LAA). Besides the IWK procedures and guidelines, RLU also has refer the government documents in their day to day works such as NLC, Federal Lands Commissioner Act 1957 (FLC Act), FC and LAA. All these procedures, guidelines and government documents are used by RLU starting from the processing of handing over of land until it was gazetted to ensure the sewerage land were managed properly. The government documents also is used in managing the sewerage land, such as to overcome the squatter issues.

In reducing the increasing of operating and maintaining cost, IWK has done a lot of initiative such as closing the small and uneconomical STPs. Referring to the existing procedure, the CA will notify the RPU to drop this STP from the asset database. Only one procedure used by RPU in managing the sewerage land and it is known as the 'Asset Management Procedure'. Based on this procedure, when the STP was rationalized, RPU will drop the asset number of this STP in the asset database system known as Asset Management Information System (AMIS). Then RPU will prepare a 'Revocation Letter' and send out to notify the JPP and related parties that this STP is no longer under operation and maintenance by the IWK. Effective from $1^{\text {st }}$ January 2016, JPP is responsible for taking over the function of maintaining and handing over the former sewerage land that has been rationalized to the land owner or land controller.

IWK has received a lot of complaints from the public regarding to the rationalized sewerage site. The major issues received by IWK are the encroachment into former sewerage land. To overcome this arising issues, IWK has developed a new procedure called 'Decommissioning or upgrading of plant'. The main objective of this procedure is to provide UO with the necessary guidelines and requirements for dropping or upgrading of existing assets and managing any complaint related to the assets. Besides that, it is also to keep the decommissioned or upgraded assets tidy and maintained and to prevented from neglected, buried and forgotten. In order to managing public complaint on decommissioned plant, any complaint received by the public needs to be informed to the JPP through a letter known as 'Notification of complaint received from the public at decommissioned plant'. For this, UO need to submit the letter to ensure that the authority (JPP) is aware on the issue raised by the public since the decommissioned plants is under JPP's responsibility and they is responsible to handle complaints received related to decommissioned plants.

As a conclusion, the existing procedures and guidelines used by IWK is to ensure that the sewerage land is managed properly starting form handed over until the sewerage land is not used anymore although the power of IWK against land is quite limited. 


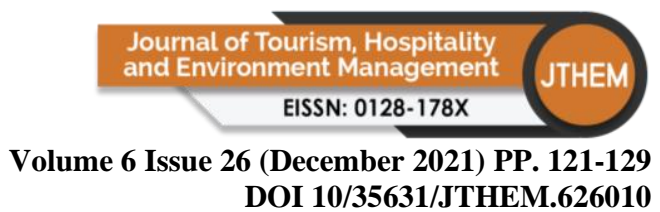

\section{Federal Constitution}

The federal government through Section 3, Sewerage Service Act 1993 (Act 508), has been given an executive authority in managing all matters related to the sewerage system and its services nationwide. The National Land Council (MTN) during the discussion the MTN paper with file reference 'MTN Bil. 5/55/1999' dated 26 $6^{\text {th }}$ October 1999 has agreed that the state government $(\mathrm{PBN})$ to reserve the land for sewerage project purposes to the federal government to be gazetted as 'public sewerage site'. It is referring to the Clause (7) of Article 83 of the Federal Constitution by applying Section 62 of the NLC and appointing the FLC as a land's controller and maintained by the JPP.

For the land registered under individual, developer or LA, this land must be transferred to FLC with a nominal payment of RM 1.00 per lot. Then the FLC will hand over this land to the PBN under Clause (1) of Article 86 of the Federal Constitution by applying Section 197 of the NLC to enable PBN to gazette this land as a federal reserve for the purpose of 'public sewerage site'.

\section{National Land Code 1965}

There are several sections in the NLC that are referred and used by RLU in the process of handing over of land owned by the developer to IWK before it was gazetted as a sewerage land site. The related sections is:-

i. Section 62 - Power of reservation of State land

ii. Section 197 - Applications for approval of surrender of whole land

iii. Section 200 - Applications for approval of surrender of part of land

iv. Section 204A - Application for approval of surrender and repossession

v. Section 215 - Form, and effect generally, of transfer of land

vi. Section 217 - Form and effect of transfer of undivided share

vii. Section 218 - Form of transfer of lease or charge

For land verification and reservation purposes, only 3 section of the NLC were used by RLU and it is Section 197, Section 200 and Section 204A using Form 12A, Form 12B and Form $12 \mathrm{D}$.

\section{Malaysian Sewerage Industry Guidelines $3^{\text {rd }}$ Edition Volume 4}

This procedure was used by IWK when the CA received an application from the developer to build the new STP for their development. Current practice by IWK, if the new development site is nearest to the existing sewer line, the developer will be advised to connect the PE of their development to the existing STP maintained by the IWK. If the connected PE of the new development will cause the current PE (CPE) of the existing STP bigger than the design capacity (DPE), the developer will be advised to upgrade to the new DPE based on an existing land area.

In case the new development is far from the existing IWK catchment, the developer is requested to provide the suitable land area based on their development PE. Referring to Section 8 of the MSIG, the recommended land area requirements for various sewage treatment plant capacities are derived from relevant treatment process concepts and also taken into consideration other design criteria. The land area requirements and buffer allowance for temporary sewage treatment plants maybe reduced at the discretion of the Commission on a case by case basis. 
The example of recommended land area requirements for Class 2 plants are given in Table 1 below. The net area does not include the 30 meter buffer zone surrounding the plant, but does include appropriate setbacks and access paths within the plant. The area requirements given are sufficient to achieve an effluent conforming to Standard A discharge requirements. It is important that allowance is made for sufficient buffers in planning approvals, to avoid future complaints in relation to the siting of the plant.

Table 1: Land Area Requirement for Class 2

\begin{tabular}{|c|c|c|}
\hline \multirow{2}{*}{$\begin{array}{c}\text { Population } \\
\text { Equivalent }\end{array}$} & \multicolumn{2}{|c|}{ Land Area Requirement } \\
\cline { 2 - 3 }$(\mathbf{m 2})$ & (acre) \\
\hline 1100 & 1115 & 0.276 \\
\hline 1200 & 1160 & 0.287 \\
\hline 1300 & 1200 & 0.297 \\
\hline 1400 & 1240 & 0.306 \\
\hline 1500 & 1275 & 0.315 \\
\hline 1600 & 1310 & 0.324 \\
\hline 1700 & 1340 & 0.331 \\
\hline 1800 & 1370 & 0.339 \\
\hline 1900 & 1395 & 0.345 \\
\hline 2000 & 1420 & 0.351 \\
\hline 3000 & 2226 & 0.550 \\
\hline 4000 & 2671 & 0.660 \\
\hline 5000 & 3076 & 0.760 \\
\hline
\end{tabular}

Source: Malaysian Sewerage Industry Guidelines $3^{\text {rd }}$ Edition Volume 4

\section{Methodology}

There is one method used in this study, it is an analysis of the government documents and an existing procedure or guidelines used by IWK during handing over process of sewerage land until it was dropped from IWK maintenance. The finding from the literature review, a procedure or guidelines related to the sewerage land are only used by the CA, RLU, RPU and UO. It found that this 4 units use a different procedure or guidelines based on their functions.

All these procedures, guidelines and government documents was analyzed using content analysis method, to see what is their advantages and disadvantages. Then a results of this analysis will be used as a basis for the formation of an effective planning model. It can be done when the results of this analysis are combined to analyze the suitability of its use. This new planning model should contain the process of planning stage, the process of land handing over to the IWK, process of land management for active STP and future planning of former STP sites after it was rationalized.

\section{Main Results}

From the analysis result, it is found that the role and function of IWK in sewerage land management for public STP and former STP are quite limited. The function of IWK in sewerage land management was started by the CA during handing over process of STP to IWK to be gazetted as a 'public sewerage site'. Then RLU will do the land verification and land reservation process also to do a follow-up with LA until this new site was gazetted. This 


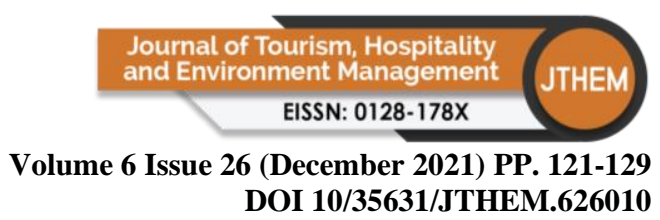

STP will be maintained by IWK until it was closed. Another function of RLU is to assist the internal or external parties for any issues related sewerage land such as a squatter issue. Normally, RLU will referring and seeking an advice from the related LA in order to resolve this arising issues.

There is a lot of STP has been rationalized under rationalization program, properties connection project and cost optimization. Under the existing procedure called asset data management control by RPU, this rationalized STP will be dropped from asset database and the operation maintenance works of this STP will be stopped. After that, RPU will prepare the revocation letter and will notice all the related parties such as JPP. Effective from $1^{\text {st }}$ January 2016, all the former sewerage site of rationalized STP will be surrendered back and maintained by the JPP until it was handed back to the land owner. Based on the existing procedure, the IWK doesn't have any authority over the former sewerage site, especially to handle issues arising by the public and also in redevelopment purpose.

Thus, the new sewerage land management model seen necessary to be developed to improve all the existing weaknesses. All the existing procedure and guidelines used by 4 units need to be combined and then controlled by one unit only. The new sewerage land management model is one of the methods to achieving the strategic land development in IWK. It will help the IWK managing sewerage land easily, to do a proper planning for new development, future planning in redeveloping the former STP land, reduce an environmental issues and to generate an extra income. The finding getting from the result of content analysis for each unit in IWK on sewerage land management has summarized in the Table 2 below.

Table 2: A Comparison of an Existing of Procedure and Guidelines on Land Matters Used By CA, RLU, UO and RPU

\begin{tabular}{|c|c|c|c|}
\hline $\begin{array}{l}\text { State Certification } \\
\text { Agency (CA) }\end{array}$ & $\begin{array}{c}\text { Regional Land Unit } \\
\text { (RLU) }\end{array}$ & $\begin{array}{c}\text { Operation Unit } \\
\text { (UO) }\end{array}$ & $\begin{array}{l}\text { Regional Planning } \\
\text { Unit (RPU) }\end{array}$ \\
\hline $\begin{array}{l}\text { To compile the } \\
\text { required land } \\
\text { documents before } \\
\text { handing over the STP } \\
\text { to IWK. It is:- } \\
\text { 1. Covering letter } \\
\text { from the developer. } \\
\text { 2. Confirmation letter } \\
\text { of STP site from the } \\
\text { developer or land } \\
\text { office. } \\
\text { 3. Pre-comp plan } \\
\text { with PT No., } \\
\text { certified by Licensed } \\
\text { Land Surveyor and } \\
\text { approved by State } \\
\text { Planning Authority. } \\
\text { 4. Form 12A / 12B / } \\
\text { 12C / 14A - } \\
\text { endorsed and }\end{array}$ & $\begin{array}{l}\text { The functions of } \\
\text { RLU on land matter } \\
\text { is:- } \\
\text { 1. To do a land } \\
\text { verification. } \\
\text { 2. To do a land } \\
\text { reservation. } \\
\text { 3. To do a follow-up } \\
\text { with related agencies } \\
\text { until the land was } \\
\text { gazetted as a site for } \\
\text { sewerage treatment } \\
\text { plant. } \\
\text { 4. To do a land } \\
\text { acquisition for new } \\
\text { sewerage site } \\
\text { planning such as to } \\
\text { build a regional STP } \\
\text { funded by Malaysia } \\
\text { government under }\end{array}$ & $\begin{array}{l}\text { The functions of UO } \\
\text { on land matter is:- } \\
\text { 1. To do a house } \\
\text { keeping such as grass } \\
\text { cutting. } \\
\text { 2. Managing public } \\
\text { complaint on } \\
\text { decommissioned } \\
\text { STP. Any complaint } \\
\text { received by public } \\
\text { needs to be informed } \\
\text { to JPP through a } \\
\text { letter known as } \\
\text { 'Notification of } \\
\text { complaint received } \\
\text { from the public at } \\
\text { decommissioned } \\
\text { plant'. }\end{array}$ & $\begin{array}{l}\text { The function of RPU } \\
\text { on land matter is:- } \\
\text { 1. To prepare a } \\
\text { 'revocation letter' for } \\
\text { rationalized STP and } \\
\text { noticed the JPP also } \\
\text { the related parties. }\end{array}$ \\
\hline
\end{tabular}


stamped received by

Land Office.

5. For the reserved land, need to submit the covering letter together with copy of gazette notification and certified plan.
Malaysia Plan

(RMK) budget.

5. To update the land information of STP in land database.

6. To prepare a report for rationalized STP and submit to JPP.

DOI 10/35631/JTHEM.626010

Source: Analysed by a Researcher Based On an Existing Procedure and Guidelines

\section{Conclusion}

The conclusion getting from this content analysis is the existing procedure and guidelines of handing over and land management in IWK need to be improved. It looks very necessary in producing a new land model where it can be used in managing the new, current and former sewerage land. The strategic land development will be able to help the IWK in reducing the number of increasing STP every year and it is one of the methods to achieve a 'sustainable development'. The improvement of the existing procedure and guidelines of handing over and land management also can help IWK to generate an additional income with redeveloping a former sewerage site. Lastly, using the integrating with other technology such as a GIS application and mapping technology will help the development of land in IWK to be more efficient and effective.

\section{References}

Akta 56, Kanun Tanah Negara, 1965

Akta 508, Akta Perkhidmatan Pembetungan (APP), 1993

Berita Harian (2012) Caj pembetungan IWK paling rendah. Thursday 10/5/2012 [cited 15/4/2019].

Retrieved

from

https://www.iwk.com.my/cms/upload_files/news/news_file_000292.jpg

Berita Harian (2018) Pelan transformasi IWK 2020 tumpu 4 tema. Friday 5/1/2018 [cited 2/4/2019].

Retrieved from https://www.bharian.com.my/bisnes/korporat/2018/01/371473/pelan-transformasiiwk-2020-tumpu-4-tema

Edaran Khas KPTG Bil 1/2008 (2008) Permohonan Perizaban Tanah Kerajaan Bagi Maksud Sistem Perkhidmatan Pembetungan, 27 Februari 2008.

Garis Panduan Perancangan Perumahan (2014), Jabatan Perancangan Bandar dan Desa Semenanjung Malaysia, Kementerian Kesejahteraan Bandar, Perumahan dan Kerajaan Tempatan.

Federal Constitution of Malaysia. Retrieved from http://www.jac.gov.my/spk/images/stories/10_akta/perlembagaan_persekutuan/federal _constitution.pdf

Foziah Johar, Ahris Yaakub, Noordini Che Man dan Susilawati Sulaiman. (2006). GIS in Development Control Process: The Case of Development Control System for City Hall of Kuala Lumpur. Kertas kerja ini di bentangkan di $6^{\text {th }}$ ASIAGIS Conference, Malaysia, 9-10 Mac 2006.

Ian Masser (2001). Managing our urban future: the role of remote sensing and geographic information systems. Habitat International. Volume 25, Issue 4, December 2001, Pages 503-512 


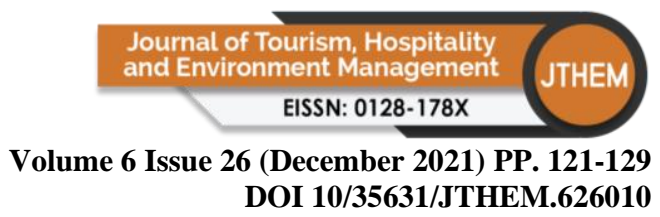

Jan Nederveen Pieterse (2001). Development Theory: Deconstructions/Reconstructions. (Sage Publication Ltd, London), 35-52

Kumpulan Media Karangkraf (2018) Kos rawatan kumbahan meningkat. Monday 22/10/2018 [cited 2/4/2019]. Retrieved from https://www.karangkraf.com.nasional/kos-rawatankumbahan-meningkat-1.895162

Lew Kin Yoon (2010). Kaedah Pembangunan Semula Kawasan Brownfield, Kajian Kes: Connaught Avenus. (Tesis Sarjana). Fakulti Kejuruteraan Dan Sains Geoinformasi, Universiti Teknologi Malaysia.

Malaysian Sewerage Industry Guidelines $3^{\text {rd }}$ Edition, Volume 4, National Water Services Commission (SPAN)

Mohd Faris Dziauddin \& Prof Madya Dr Ruslan Rainis. (2001). Pemodelan Pembangunan Guna Tanah Komersil Menerusi Aplikasi Sistem Maklumat Geografi (GIS) Kes Kajian: Seberang Perai Tengah, Pulau Pinang. Jurnal Teknologi. 35(B). pp 23-40.

Mohd Rozaimi Ariffin, Zaini Sakawi \& Lukman Ismail (2013). Perpepsi Impak Pencemaran Bau Dari Loji Sisa Kumbahan Ke Atas Psikologi, Fisiologi Dan Kesihatan. Institut Alam Dan Tamadun Melayu (ATMA). Universiti Kebangsaan Malaysia.

MStar (2016) IWK tutup lebih 500 loji sekitar Lembah Klang. Monday 17/10/2016 [cited 2/4/2019]. Retrieved from https://www.mstar.com.my/niaga/2016/10/17/iwk-tutuploji

Ruslan, R. and Noresah, M. S. (2004) Modelling urban land use dynamic using GIS and Markov Chain Model. Geoinformation Science Journal 4 (1): pp. 72-81. ISSN 15519491.

Sinar Harian (2018) IWK tumpu cari sumber pendapatan alternatif. Friday 14/12/2018 [cited 2/4/2019]. Retrieved form http://www.sinarharian.com.my/nasional/iwk-tumpu-carisumber-pendapatan-alternatif-1.915422

Sinar Harian (2018) Kos rawatan kumbahan meningkat. Sunday 22/10/2018 [cited 2/4/2019]. Retrieved from http://www.sinarharian.com.my/nasional/kos-rawatan-kumbahanmeningkat-1.895162 